\title{
Die lewe en werk van Martin Luther (1483-1546):'n Leksikografiese bydrae tot Reformasie 500
}

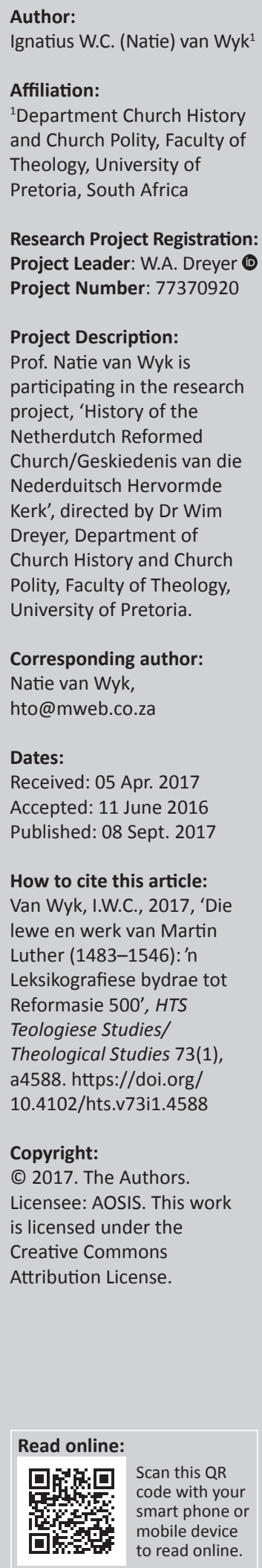

Scan this QR code with your smart phone or mobile device to read online.

This is a lexicographic contribution to Reformation 500. The life, work and legacy of Martin Luther is discussed. The article wants to introduce Martin Luther to readers who are not acquainted with him. After reading the article readers should know a few basic facts of his complicated biography. They should have an idea of the themes he discussed, where his works could be accessed and the latest literature relating to Luther. We also let Luther himself speak to us via his table-talks. Through the selected table-talks, one gets to know Luther as the family man who dearly loved his wife and children. A few hundred words cannot do justice to the legacy he left behind. The short notes on his huge legacy want to motivate the reader to read more about the man who changed the course of history.

\section{Lewe}

\section{Lewensloop}

1483 Martin Luther word op 10 November as seun van Hans en Margerethe Luder in Eisleben gebore.

1484 Die familie verhuis na Mansfeld, waar Martin tussen 1488 en 1497 skoolgaan.

1497 Skoolonderrig in Magdeburg.

1498 Luther verskuif na die 'predikanteskool' St Georg in Eisenach.

1501 Luther begin met filosofiestudies aan die Universiteit van Erfurt.

1502 Luther ontvang op 29 September 'n Baccalaureus in die Vrye Kunste.

1505 Ná afhandeling van die Magister Artium, begin hy om Regte te studeer. Op 02 Julie sterf hy byna in 'n storm by Stotterheim en belowe om priester te word. Op 17 Julie neem hy sy intrek by die Augustynse-Eremiten Orde.

1507 Luther word op 04 April tot priester gewy en hy begin op 02 Julie met sy teologiese studies op 24-jarige leeftyd.

1508 Luther doseer moraalfilosofie in Wittenberg.

1509 Luther behaal die graad Baccalaureus Biblicus.

1510 Reis na Rome ter wille van administratiewe aangeleenthede.

1511 Luther neem sy permanente intrek in die klooster in Wittenberg en woon daar tot sy dood.

1512 Luther promoveer tot Doktor in die Teologie.

1513 Hy doseer as professor aan die Universiteit van Wittenberg. Hy word ook aangestel as die visehoof van sy klooster en prediker van die stadskerk.

1515 Luther word verkies tot distriksvikar en toesighouer oor 11 kloosters.

1517 Op 31 Oktober skryf hy 'n uitnodiging tot disputasie aan aartsbiskop Albrecht van Mainz, met as aanhangsel sy 95 stellings teen die aflaatstelsel. Die vermoede bestaan dat óf hy, óf die 
sekretaris van die Universiteit hierdie disputasiestellings teen die kerkdeure van Wittenberg vasgespyker het.

1518 Die Roomse Kerk begin met'n klag teen hom. In Augsburg word hy deur die pouslike gesant, Cajetan, verhoor.

1519 Luther en sy kollega, Karlstadt, disputeer in Leipzig met Johannes Eck.

1520 Die Pous dreig Luther met die ban. Hy verbrand die dreigbrief ('bul') in die openbaar.

1521 Op die Ryksdag van Worms eis Luther weerlegging van sy standpunte op grond van die Skrif alleen. Keiser Karel V wil hom in hegtenis neem, maar keurvors Frederik die Wyse versteek hom op Wartburg as Junker Jörg. Binne 11 weke vertaal hy die Nuwe Testament in Duits.

1522 In die volgende jare word Luther die mees gelese Duitse teoloog.

1524 Luther trek sy priestergewaad uit en bedank uit die Augustynse Orde.

1525 Hy trou met die gewese non Katharina von Bora. Die egpaar het ses kinders. Hy poog om die boereopstande te stuit.

1529 Vergader met ander Reformatore in Marburg oor die Nagmaalkwessie.

1530 Op die Ryksdag van Augsburg word Melanchthon se Confessio Augustana as Protestantse belydenisskrif aanvaar terwyl Luther in Coburg skuil.

1534 In September verskyn die eerste volledige Bybelvertaling (Lutherbybel).

1536 Luther skryf gedurende Desember die Schmalkaldiese Artikels ('n geloofsbelydenis).

1537 Luther neem in Schmalkalde deel aan die vorming van die Schmalkaldiese Bond. Luther word siek.

1533 Op 05 Oktober wy Luther die Kasteelkerk in Torgau in as die eerste kerk wat deur Protestante self gebou is.

1546 Luther sterf op 18 Februarie in Eisleben. Op 22 Februarie word hy deur sy kollegas, Melanchthon en Bugenhagen, in Wittenberg begrawe. ${ }^{1}$

\section{Lewensverhaal}

Dit is onseker wat Martin Luther se geboortejaar is. Volgens (vermoedelik) sy eie weergawe (WA TR 5,5362), is hy op 10 November 1484 in Mansfeld gebore. Volgens sy eerste asook die nuwe Lutherbibel (2017:5-31). biograaf, Phillip Melanchthon ([1546] 2011b:180), is hy egter in 1483 gebore. Die teologiese tradisie volg die Melanchthonweergawe (Dietrich [2008] 2013:15-19; Leppin [2006] 2010a:16; Schilling 2014:24). Hy is op 11 November gedoop en sterf op 18 Februarie 1546 in die ouderdom van 63 jaar. Hy is op 22 Februarie in die Schloßkirche [Kasteelkerk] in Wittenberg begrawe.

Martin Luder was die seun van Hans en Margarete Luder van Eisleben, Duitsland. ${ }^{2}$ In 1484 verhuis die familie na Mansfeld, en in 1488 begin hy dáár met sy Latynse skoolonderrig. In 1497 wissel hy na die skool van die Brüdern vom gemeinsamen Leben [Broeders van die Gemeenskaplike Lewe] in Magdeburg. Een jaar later, in 1498, besoek hy die Pfarrschule [predikanteskool] van St Georgen in Eisenach (vgl. Kohnle 2015:24-33; Schilling [2012] 2014:56-73).

In 1501 begin hy met sy studie aan die Universiteit van Erfurt (een jaar vóór die stigting van die Universiteit van Wittenberg op 18 Oktober 1502). In Januarie 1505 promoveer hy tot Magister Artium en in Mei begin hy met regstudie, maar beleef op 2 Julie die storm te Stotternheim. Hy belowe om 'n monnik te word. ${ }^{3}$ Op 17 Julie neem hy sy intrek in die Augustynse klooster te Erfurt. In 1506 lê hy sy beloftes af, en op 03 April 1507 word hy as priester gewy. ${ }^{4} \mathrm{Hy}$ begin met sy teologiese studie en raak bevriend met Johannes von Staupitz. In 1508 beroep Staupitz Luther na Wittenberg om Moraalfilosofie te doseer. In Maart 1509 behaal hy 'n Baccalaureus in Teologie en keer tydelik na Erfurt terug. Nadat hy vir ' $n$ jaar in Rome was, keer hy in 1511 na Wittenberg terug as onderhoof van die Augustynse Klooster en dosent in teologie. Op 19 November 1512 promoveer hy tot doktor in die Teologie en begin hy met sy voorlesings oor Genesis (vgl. Dietrich [2008] 2013:39-51; Kohnle 2015:34-45; Köpf 2015:18-37; Leppin [2006] 2010a:28-106; Schilling [2012] 2014:74-112).

Luther het as gedoktoreerde dosent (doctor theologiae) twee opdragte gehad, naamlik voorlesings en disputasies. Die disputasies het aan hom die geleentheid gegee om sy Reformatoriese insigte in stellings op skrif te stel, wat krities

2.Luther het enkele biografiese brokkies in sy tafelgesprekke met die deelnemers gedeel. Ek bied hier ' $n$ Afrikaanse vertaling van enkeles aan. Ek voorsien die aanhalings met die volume van die WA TR plus die nommer van die gesprek, asook aanhalings met die volume van die WA TR plus die nommer van die gesprek, asook die bladsynommer van Dithmar (2010) se aangepaste weergawe van die spesifieke uitspraak. 'My vader was in sy jeug ' $n$ arm boerseun. My moeder het al haar hout op die rug gedra. Net só het sy ons ook [gedra] en grootgemaak' (WA TR 3, 2888a = Dithmar 2010:19). Verder: 'Ek is' $n$ plaaskind. My voorouers, my oupa en my pa was werklike boere gewees. My vader het [later] na Mansfeld getrek en dáár op die myn gaan werk. Dít is wie ek is! Ek het egter'n Baccalaureaat, 'n [man met]' $n$ Magister en 'n monnik geword. Ek het die Pous in die hare gevlieg, en hy vir my. Ek het 'n weggeloopte non as vrou geneem. Sou die sterre dít ooit kon voorspel? Wie sou dít vir my kon beloof het?' (WA TR 5, 6250 = Dithmar 2010:19).

3.Luther se besluit het nie sy pa se goedkeuring weggedra nie. Wat hy aan tafel verte het, is só genotuleer: 'Martin Luther het monnik geword desondanks die heftige weerstand van sy vader. Toe hy sy vader aan tafel, by die geleentheid van sy eerste misviering, gevra het waarom hy aanstoot geneem het aan die monnikedom, het hy [bombasties] geantwoord: "Weet jy nie dat daar geskryf staan, eer jou vader en jou moeder nie?" Toe hy as verskoning vertel dat hy weens die storm so verskrik was, dat hy hom verplig gevoel het om 'n monnik te word, het die vader geantwoord: "Maak net seker dat nie'n spook was nie"' (WA TR 1, 623 = Dithmar 2010:20).

4.Luther self het die volgende oor sy besluit gesê: 'Ek wou nie graag'n monnik word nie. Die wêreld gluur my egter nóu so aan asof ek graag'n monnik wou word. Dit is 'n onreg om ' $n$ woestynpad te bewandel en om uit die blikveld van die skandalige wêreld te kom' (WA TR 2, 2286 = Dithmar 2010:20). 
deur vriende, studente en teenstanders bespreek is. Hierdie proses het hom gehelp om sy standpunte te herdink en te presiseer. Die disputasies was ook die voertuig waarmee die Reformatoriese gedagtegoed aan die breë bevolking bekendgestel is. Die disputasies was gedruk op 'n plakkaat wat teen die deure van kerke en universiteitsgeboue vasgespyker is. Alle verbygangers kon dit dus lees. Sy beroemde 95 stellings teen die aflaat ${ }^{5}$ (WA 1, 233-238) van 31 Oktober 1517 het wêreldkundig geword danksy die disputasiestelsel.

Ter wille van duidelikheid: 'n Disputasie is 'n kritiese gesprek oor 'n reeks stellings wat oor 'n bepaalde tema opgestel is. Die disputasies van die laat-Middeleeue het min ruimte gelaat vir 'n kritiese gesprek oor die amptelike standpunte van die Rooms-Katolieke Kerk. Luther se deurbraak was dat hy die moed van sy oortuiging gehad het om pouslike dekrete en konsiliebesluite krities te debatteer. Hierdie kritiese debat was deel van die buitengewone disputasies, en nie deel van die gewone kritiese debat met die studente (disputatio circularis) of die verdediging van proefskrifte (disputatio pro gradu) nie. Hierdie buitengewone disputasies het vanselfsprekend baie kerklike en publieke aandag geniet. Dit was veral sy kritiek teen die aflaatstelsel en die Skolastieke teologie wat wye belangstelling geniet het. Wat ons vandag as 'kritiese teologie' ken, het sy oorsprong by Luther. Krities beteken: om alle besluite van vorige vergaderings en alle geskrifte van vorige geslagte en alle uitsprake van tydgenote krities te evalueer aan die hand van die kerk se primêre bron, die Bybel. Kritiese denke word selde geduld; daarom moet Luther se voorbeeld gevolg word deur te sê hier staan ek, ek kan nie anders ${ }^{6}$ nie aangesien die Bybelse boodskap van my verwag om hier te staan (vir omvattende inligting in Afrikaans, kyk na van Wyk 2016; 2017a; 2017b. Vir verdere inligting kyk na Leppin 2010b; Schwarz 2010).

Rondom die jubileumdatum, 31 Oktober 1517, is daar 'n biografiese brokkie wat vermelding verdien. Op hierdie dag het Martin Luder 'n brief aan aartsbiskop Albrecht van Mainz

$5.5 y$ kritiek teen die aflaatstelsel (vgl. Hamm 2016 vir omvattende inligting oor hierdie eeue-oue dispuut) was die beginpunt van sy kritiek teen'n hele reeks sake. In sy eie woorde: 'Destyds het Tetzel sy aflaatpreke in Jüterbog gelewer, en die mense he soos besetenes agter hom aangeloop. Spoedig daarna het ek begin om mense af te raai [om hom te volg] en om aan hulle te verduidelik wat genade en vergewing van sondes is. Maar toe Tetzel skaamteloos [hiermee] aanhou, het ek die stellings oo die aflaat gepubliseer. Dít het die ganse wêreld in opstand gebring. Destyds het ek nog die Pous as my meester erken. Ek het geglo dat ek hom'n guns doen, met ek nog die Pous as my meester erken. Ek het geglo dat ek hom ' $n$ guns doen, maar hy het my met alle mag beveg. Daarom moes ek my verweer, en het dit ook waarli gedoen, tot die aflaat, klooster, Mis en instituut tot' $n$ val gekom het. En die Pous he aangeval. En deur swakheid sal Hy hom tot ' $n$ val bring, ook al brul en raas die duiwel' (WA TR 5, 5346 = Dithmar 2010:23).

6. Hierdie woorde word verkeerdelik aan Luther toegedig. Op 16 April 1521 word hy deur Johannes Eck, die assistent van die Aartsbiskop van Trier, aangekla. Op 18 April 1521 antwoord Luther op die aanklag en die versoek van die Pous. Luther weier om sy geskrifte terug te trek en sê die volgende: '... indien ek nie deur die getuienisse van die Skrif en duidelike rasionele argumente oortuig kan word nie - aangesien ek nie die pous of die konsilies kan glo nie, omdat dit ' $n$ feit is dat hulle dikwels gefouteer en mekaar weerspreek het - daarom is ek op grond van my aanhalings uit die Heilige Skrif in my gewete oortuig [dat ek reg is] en'n [daarom]'n gevangene van die Woord van God. Om hierdie rede kan en wil ek niks herroep nie, aangesien dit die Woord van God. Om hierdie rede kan en wil ek niks herroep nie, aangesien dit nie veilig of heilsaam is om teen die gewete te handel nie. Mag God my help, Amen ." Volgens tradisie (uit latere vlugskrifte) sou Luther aan die einde gesê het "Hier staan ek. Mag God my help. Ek kan nie anders nie". Hierdie woorde word egter nie deur die notule van die Ryksdag, of ' $n$ ooggetuie ondersteun nie. Volgens een van die ooggetuies, Konrad Peutinger, sou hy gesê het: "Mag God my tot hulp wees!" Beide hierdie weergawes word nie as histories betroubaar aanvaar nie' (vgl. Kohnl
2015:108-115; Leppin [2006] 2010:171-181; Schilling [2012] 2014:218-223). geskryf. Vir die eerste keer onderteken hy 'n brief as Martin Luther. Hierdie naamsverandering simboliseer sy nuwe selfverstaan - 'n mens wat danksy die ontdekking van die hart van die evangelie vry is. Sy nuutgevonde evangeliese vryheid bring hom daartoe om sy benaming met Eleutherius uit te brei. Van hier af heet hy Frater Martinus Eleutherius Luther - verteenwoordiger van die vryheid van die evangelie (vgl. Schilling [2005] 2010:101 en Zschoch [2005] 2010:82).

Luther het oornag 'n 'mediaster' geword. Hy was die eerste persoon wat die moontlikhede van die boekdrukkuns ten volle benut het. Honderde van sy geskrifte was in die vorm van 'vlugskrifte' - 'n dun boekie van 'n paar bladsye wat vinnig gedruk en versprei kon word. Sy Bybelvertalings, kategismusse en selfs akademiese verhandelings het binne weke in tienduisende verkoop. Luther was die eerste teoloog wat die publiek teologie laat lees het; hoofsaaklik deur sy benutting van die 'media'. Luther sou nooit só suksesvol gewees het sonder die nuwe media nie (vgl. Leppin [2006] 2010a:151-164, 2016:72-75).

Luther was ook om 'n ander rede suksesvol in sy stryd om die kerk weer terug te bring na die Woord. Hy het die steun geniet van enkele vorste. Die stryd om die Reformasie was ook 'n politieke stryd. Die keiser het die Rooms-Katolieke posisie en belange beskerm. Was dit nie vir mense soos keurvors Frederik die Wyse nie, sou Luther as ketter verbrand gewees het. Die vorste wat die Smalkaldiese Bond gevorm het, het die Reformasie militêr beskerm. Luther sou dalk nie eens die Nuwe Testament in Duits vertaal het nie, indien hy nie skuiling kon vind op die Wartburg by Eisenach nie (vgl. Leppin [2006] 2010a:258-276; Schilling [2012] 2014:445-495).

Luther se huwelik ${ }^{7}$ met Katharina von Bora in 1525 het ook'n groot rol in die vestiging van die Reformasie gespeel. Die feit dat hulle ses kinders en talle aangenome kinders gehad het, het ' $n$ ander belangrike dimensie aan die Reformasie gegee, naamlik opvoeding en onderwys. Luther se geskrif oor die huwelik (1522) en die twee geskrifte oor die onderwys (1524; 1530) het bygedra om die Europese samelewing diepgrypend te verander. Verpligte skoolonderrig soos ons dit vandag ken, het sy oorsprong by Luther en sy bondgenoot Melanchthon. Arm en verwese kinders het 'n belangrike rol gespeel om Luther so ver te kry om aan die barmhartigheidstaak van die kerk en moraliteit in die ekonomie aandag te gee. Hy het dit gedoen deur gereeld oor hierdie vraagstukke te preek, en hieroor artikels te skryf. Verder was hy instrumenteel in die herstrukturering van sosiale instellings ten einde dienslewering te verbeter en korrupsie te bekamp (vgl. Van Wyk 2015a).

7.Luther het oor sy vrou gesê: 'Ek het my Käthe lief. Ja, ek het haar liewer as myself: dít is vir seker waar! Dit beteken: ek sal eerder wil sterf; net nie sy of die kinders nie (WA TR 2, 1536 = Dithmar 2010:32). Oor die sterfte van die 13-jarige Magdalene, of Lientjie soos hy haar dikwels genoem het, word die volgende berig: 'Toe dit met die siek do sor slegter siek dogter slegter gegaan het, het hy gese: "Ek het jou baie lief". Maar as dit U wil is, liewe Vader, dat $\mathrm{U}$ haar wil neem, wil ek die versekering hê dat sy by U sal wees. Toe het hy die volgende vir die dogter op die bed gevra: "Magdaleentjie, my dogtertjie, jy wil graag hier by jou vader bly, maar wil jy ook graag na die Vader gaan?" Die siek kind het geantwoord: "Ja, liefste vader, net soos God wil". Die vader antwoord: "Jou liewe dogtertjie! Die gees is sterk, maar die vlees is swak. Ek het jou so oneindig lief" (WA TR 5, 5954 = Dithmar 2010:35). 
Vandat dit geblyk het dat die Rooms-Katolieke Kerk nie maklik gaan hervorm nie, het Luther 'n groot rol gespeel in die opbou van 'n nuwe kerk. Drie sake is noemenswaardig: Luther het rigtinggewende bydraes gelewer ten opsigte van die kerklike orde. Hy het die eerste kerkorde geskryf (Johannes Bugenhagen sou hierdie taak by Luther oorneem). Hy het verder liturgieë vir die erediens uitgewerk sodat die 'evangeliese gemeentes' op 'n unieke wyse kon kerk wees. Aangesien die prediking sentraal staan in die 'nuwe kerk', het Luther 'postilles' geskryf waarmee hy aan die predikante leiding gegee het oor hoe daar in die Protestantse Kerk gepreek moet word. Luther en Melanchthon het gou besef dat visitasie ('n amptelike kerklike besoek aan gemeentes) 'n dringende noodsaaklikheid is. Hulle vermoede is gou bevestig dat die predikante nie opgewasse en toegerus was vir hulle taak nie. Dié wat uit die Roomse Kerk na die Reformasie oorgekom het, het in die meeste gevalle feitlik geen teologiese opleiding gehad nie. Ander opportuniste was weer lui en traag om teologie te lees. Dit was die visitasieverslae wat Luther gedwing het om die kategismusse te skryf. Hy moes die predikante en die familiehoofde iets in die hand gee waarin die hoofpunte van die evangelie saamgevat en verduidelik word, sodat hulle kon preek en kategese aanbied (vgl. Kohnle 2015:164-185; Leppin [2006] 2010a: 209-220, 267-276; Schilling [2012] 2014:353-444).

\section{Werk}

Luther het tydens sy relatiewe kort lewe geweldig baie geskryf. Deur die genade het die meeste van sy skryfwerk behoue gebly. Tydens die jubileumjaar van 1883 (die 400 -jarige herdenking van sy geboorte) is daar met 'n projek begin om al sy bewaarde geskrifte, georden volgens ouderdom, as versamelde werke te publiseer. Hierdie proses is nog steeds nie afgehandel nie. Hierdie Versamelde Werke word soos volg aangedui:

- Luther, M., 1883-1929, Weimarer Ausgabe (WA, WA DB en WA TR), D. Martin Luthers Werke: Kritische Gesamtausgabe, 65 Bände, H Böhlaus und Nachfolger, Weimar.

Hierdie Versamelde Werke, ook bekend as die Weimarer Ausgabe (WA), is danksy die elektroniese media beskikbaar op Internet. Die volgende skakels kan gebruik word:

- www.CheckLuther.com

- www.lutherdansk.dk/wa

- www.hab.de

- www.zvab.de

Daar bestaan 'n hele aantal uitgawes wat 'n seleksie van Luther se belangrikste werke bevat. Die uitgawe wat tans die meeste gebruik word, is:

- Martin Luther, 2006-2009, Lateinisch-Deutsche Studienausgabe, Evangelische Verlagsanstalt, Leipzig (3 volumes).

- Martin Luther, 2012-2017, Deutsch-Deutsche Studienausgabe, Evangelische Verlagsanstalt, Leipzig (3 volumes).

Biografie en teologie kan nie by Luther heeltemal geskei word nie. Luther se persoonlike geloofsworsteling, sy geskille met Rome, sy belewenis van die boereopstande, sy afhanklikheid van die politieke maghebbers en briefwisseling met mense wat allerlei probleme ervaar het, het alles bepaal wat en hoe Luther geskryf het. Aangesien Luther so baie geskryf het, is dit onmoontlik om binne die bestek van 'n paragraaf ' $n$ oorsig te gee van sy geskrifte. Ek beveel aan dat my reeks kort artikels oor Luther se geskrifte gelees word om 'n idee te vorm van die temas, sy skryfstyl en die kerngedagtes van sy teologie. Hierdie artikels is opgeneem in die Tydskrif vir Hervormde Teologie (2017/1).

Naas die korter en langer geskrifte, het Luther ook 'n reeks kommentare oor Bybelboeke geskryf wat ook in die WA gevind kan word. Dan is daar natuurlik ook Luther se Klein en Groot Kategismusse (1529) en sy Bybelvertalings. Persone wat hierin belangstel en nie Duits magtig is nie, kan Engelse vertalings aankoop by: The Luther Academy, St. Louis, Missouri (Concordia Publishing House). Engelse vertalings is deesdae ook elektronies (as pdf-dokumente) beskikbaar. Talle van hierdie geskrifte is gratis op die web beskikbaar (kyk onder andere na CheckLuther.com).

Met die naderende Luther-jubileum het daar talle uitstekende publikasies verskyn wat oorsigte bied oor Luther se teologie. Die volgende kan aanbeveel word: Al hierdie publikasies is ook in Engelse vertalings beskikbaar: Nürnberger (2005); Barth (2009); Bayer ([2003] 2007); Ebeling ([1964] 2017; Lohse (1995); Schwarz ([2015] 2016).

Daar bestaan ook baie goeie Luther-handboeke. Die volgende is die belangrikste: Beutel ([2005] 2010); Kolb, Dingel en Batka (2016); Mckim (2003).

\section{Wat het ons aan Luther te danke? Melanchthon se oordeel}

Daar is in die loop van 500 jaar duisende boeke oor Luther en sy teologie geskryf. Dit is vanselfsprekend onmoontlik om binne die ruimte van enkele bladsye reg te laat geskied aan die enorme Luther-navorsing. Ek oordeel dat die eerste huldeblyk aan Luther, nie net van historiese belang is nie, maar ook van aktuele belang. Om hierdie rede lei ek hierdie gedeelte in met Philip Melanchthon ([1546] 2011a) se 'lyksrede' tydens Luther se begrafnis. Niemand het Luther beter geken as Melanchthon nie, en daarom is sy oordeel oor Luther se lewe en werk van besondere historiese en akademiese waarde.

Melanchthon begin deur te stel dat hy nie 'n lofrede oor Luther wil lewer nie, maar sy bydrae, as werktuig van Christus, tot die leiding van die kerk, wil aantoon. Hy wys daarop dat mense wat wêrelds oor die lewe dink, glo dat alles maar blindelings en per toeval gebeur. Gelowiges glo egter dat die kerk deur God gelei en bewaar word, en dat hy daarom sorg dat daar begaafde mense kom wat die kerk volgens God se wil kan lei - en een van hulle was Martin Luther. Luther, die uitverkorene, se taak was om die kerk terug te lei na ware aanbidding, die Skrif reg uit te lê en om die evangelie van Jesus Christus te verkondig. Luther het die 
taak gehad om die 'ware en noodwendige leer' weer aan die lig te bring. Hy het daarop gewys dat die kerk nie sonder voortdurende bekering kan gedy nie. Hy het aangetoon dat diegene wat in vrees vir God se toorn lewe, in die Bybel die God van barmhartigheid kan leer ken. Hy het geleer dat die mens deur die geloof regverdig word, en dat daar tussen wet en evangelie, geestelike en wêreldlike geregtigheid onderskei moet word. Hy het die dwaasheid ontbloot dat ' $n$ mens God nog steeds kan aanroep, al word jou gemoed oorheers deur twyfel en onsekerheid oor die waarheid van die evangelie. Hy het geleer dat God slegs in die geloof, 'met 'n goeie gewete', aangeroep kan word. Hy het geleer dat gebed tot die lewende en teenwoordige Christus gerig word, en dat gebed niks met ' $n$ gepraat met beelde van dooie mense te make het nie. Hy het geleer dat die samelewing nie sonder goeie owerhede kan funksioneer nie, maar ook geleer dat gehoorsaamheid aan staatswette en-ordinansies niks met jou saligheid te make het nie. Hy het daarop gewys dat die nakoming van kerkordelike reëlings weinig met lewende geloof te make het. Laastens het hy die Bybel in Duits vertaal, sodat elkeen self kan lees en die prediking beoordeel. Deur sy pastorale advies het hy talle mense in krisismomente gehelp. Hy was 'n vriendelike en empatiese mens - ten spyte van sy ongeduldigheid en woede-uitbarstings oor lui en onbekwame mense. Hy het die kunste bevorder. Musiek en skilderkuns, was naas die teologie, vir hom die belangrikste dinge van die lewe. Hy was lief vir sy vrou en kinders en 'n goeie buurman. Hy het daagliks vir hulle en die hele kerk voorbidding gedoen. Hy het die kerk geleer dat die tyd min is op aarde. Hardwerkendheid en pligsbesef was die deugde wat hy bevorder het. Melanchthon ([1546] 2011a:175-176) sluit sy rede af met die sekere wete dat Luther wel gered is. Hy moedig die gemeente, en die nageslag, aan om Luther in herinnering te hou. Sy deugde, sy weldade en sy leer moet bewaar word. Sy voorbeeld moet ook deur volgende geslagte nagevolg word: Sy voorbeeld van volharding in gebed, weetgierigheid, hardwerkendheid en sorg vir armes en weeskinders. Tipies van Melanchthon, sluit hy sy rede met 'n gebed af. Hy dank die barmhartige Vader dat Luther die amp van predikant kom herstel het sodat die suiwer leer van die evangelie gehoor, geleer en bewaar kan word, aangesien die kerk hiermee in stand gehou word.

\section{Ons oordeel vandag}

Martin Luther, soos Melanchthon reeds te kenne gegee het, was geen heilige nie. Hy het baie tekortkominge gehad, soos woedeuitbarstings en 'n gebrek aan geduld. Boonop het hy talle oordeelsfoute begaan. Minstens die volgende kan genoem word: Hy was vyandig teenoor die Jode, hy was aanvanklik dalk té simpatiek teenoor die boere en hulle griewe; en het toe later omgedraai en hulle heftig gekritiseer weens hulle gewelddadige opstand teenoor die owerhede, weermagdiens was vir hom geen gewetenskwessie nie en hy was oortuig dat die Christelike etiek nie groot trefkrag binne die samelewing kan hê nie (vgl. Köpf 2015:123-151, 181-237; Schilling [2012] 2014:496-523,544-573). Aan die ander kant is ons baie aan Luther verskuldig. Die volgende kan kortliks genoem word: Hy het die verband tussen vryheid en die
Christelike geloof belig, die kritiese omgang met die Bybel begrond, mense oortuig om die Bybel nie as handboek vir die wêreldgeskiedenis of die wetenskap te gebruik nie, God Christosentries verduidelik, die algemene priesterskap van die gelowiges beklemtoon, aangedring op die vertaling van die Koran in Latyn, grense gestel aan die mag van maghebbers, die kinderdoop bevorder, die Duitse taal ontwikkel deur sy Bybelvertalings, ingesien dat die bose méér is as die somtotaal van bose dade, en die belangrikheid van die eskatologie vir die teologie beklemtoon (Jung 2016:9-13; Kaufmann [2016] 2017:87-90; Kohnle 2015:202215; Söding 2017).

Martin Luther wou aanvanklik enkele onaanvaarbare praktyke in die Rooms-Katolieke Kerk van die laatMiddeleeue krities beredeneer, maar het toe uiteindelik die wêreld verander. Om in ' $n$ paar sinne 'n evaluasie van sy werkingsgeskiedenis te gee, is onbevredigend. Nogtans behoort die volgende paar opmerkings 'n aanduiding te gee van wat kerke en beskawings aan Luther te danke het.

Luther het die Lutherse Kerk nagelaat (alhoewel dit nooit sy bedoeling was om 'n nuwe kerk te stig nie); hierdie Kerk tel vandag ongeveer 70 miljoen lidmate. Geslagte Lutherane is opgevoed aan die hand van die Klein Kategismus. Hierdie Kategismus het meegehelp dat miljoene Christene 'n goeie begrip het van die inhoud van die Bybel. Op grond van hulle kategetiese kennis het talle Duitsers, soos Johann Sebastian Bach (die bekendste van almal), van die mooiste musiek ooit gekomponeer (vgl. Schilling 2017). Die Lutherse musiektradisie is waarskynlik, volgens vandag se oordele, Luther se grootste nalatenskap.

Danksy Luther het Reformatoriese kerke 'n eie argitektuur ontwikkel. Kerkgeboue word binne die Reformatoriese tradisie doelmatig, met die oog op gemeentelike aktiwiteite, gebou. Die verskuiwing van die klem vanaf bisdomme na gemeentes het nuwe betekenis aan die uitdrukking 'gemeenskap van gelowiges' gegee. Kerklik hiërargiese denke het plek gemaak vir broers en susters wat op gelyke voet, saam, onder die heerskappy van Christus kan lewe (vgl. Kaufmann [2016] 2017:179-194; Kohnle 2015:164-195; Leppin 2017).

Die noue band tussen gemeentelede het meegebring dat die wêreldse nood en ellende van mense binne die gemeentes bekend geraak het. Een van Luther se groot verdienstes is dat hy die diakonaat kragdadig ontwikkel het. Hy het gesorg dat gemeentes diakonale fondse opbou en volgens streng etiese beginsels bestuur. Hy het aan die kerk die voorbeeld gestel hoe daar na siekes en weeskinders omgesien moet word. Die gedagte dat mense wat kan, weeskinders moet aanneem, is aan Luther te danke. Hy self het vier weeskinders in sy eie huishouding opgeneem en só die voorbeeld gestel in hierdie verband. Onderliggend aan hierdie eenheidsband in gesin en samelewing was sy verstaan van die 'priesterskap van die gedooptes' (vgl. Kohnle 2015:140-154; Leppin 2017; Van Wyk 2015b). 
Luther het 'n reusebydrae gelewer ten opsigte van die emansipasie van die vrou. Sy huwelik met die gewese non, Katharina von Bora, het geweldige goeie gevolge vir vroue gehad. Die status en statuur van Katharina het bygedra tot 'n ontwikkelingsproses wat ' $n$ belangrike kerklike plek en funksie vir vroue sou verseker. Luther het, teen die tradisie in, Katharina as sy enigste erfgenaam benoem. Die regsisteem van daardie tyd het sy testament ongelukkig as ongeldig verwerp. Hierdie onreg aan sy vrou en kinders sou egter nuwe impulse meebring wat bygedra het tot die transformasie van die Duitse, en later Europese, regswese en samelewingstruktuur (vgl. Kunter 2016:46-50, 186-193; Roper 2016:273-306; Strohm 2017).

Duisende studente van regoor Europa en Skandinawië het in Wittenberg studeer. Die aansien van Luther en Melanchthon het verseker dat die Reformasie van die begin af ' $n$ ekumeniese aangeleentheid was. Die intellektuele verbondenheid tussen studente, leermeesters en kollegas is 'n kosbare skat van die Reformatoriese erfenis. Die skending van hierdie erfenis is verraad teenoor die Reformasie (vgl. Kaufmann [2016] 2017:195-348; Roper 2016:363-379).

Die Reformasie het 'n sterk intellektuele komponent. Luther (en Melanchthon) het belangrike bydraes gelewer tot die intellektuele vorming van kinders en die jeug. Die gedagte van verpligte skoolonderrig vir kinders kan na Luther teruggevoer word. Hy het besef dat slegs kinders wat behoorlik kan lees en skryf, bevredigend aan die gemeentelike aktiwiteite kan deelneem. ' $n$ Kind wat nie kan lees nie, kan nie uit die Bybel en die Kategismus lees nie. 'n Kind wat nie 'n basiese kennis van geskiedenis het nie, kan nie die kerkgeskiedenis verstaan nie. Die Duitse gedagte van 'Bildung' (omvattendeintellektueleen kulturele ontwikkeling) is sonder Luther nie voorstelbaar nie (vgl. Schweitzer 2017).

\section{Die blywende waarde van sy teologie}

Die omvang van Luther se teologie maak dit nie moontlik om 'n oorsig te bied nie (kyk egter gerus na Van Wyk 2015b vir 'n inleiding in sy denke). Enkele kernelemente word eksemplaries uitgelig. Die blywende waarde van Luther se teologie is dat dit onder andere oor die geloofsvrae van die individuele gelowige handel. Sy teologie is eksistensiële teologie. Dit gaan oor ons bestaan voor die aangesig van God. Luther het as jong priester met die vraag geworstel hoe hy as mens, wat nie genoeg goeie werke kan doen nie, staande kan bly voor die oordeel van God. Hy het geglo dat God 'n God van geregtigheid is, wat mense straf na verdienste. Sy groot 'Reformatoriese deurbraak' het gekom toe hy die Romeinebrief intensief bestudeer het, en daarin ontdek het dat God, die Vader van die Gekruisigde, 'n barmhartige en genadige God is. Hy het verder ontdek dat 'n mens, slegs deur geloof, deel kry aan die barmhartigheid van God. Goeie, voortreflike werke is nie nodig om God se guns te wen nie (vgl. Barth 2009:264-276; Bayer [2003] 2007:41-61; Ebeling [1964] 2017:120-136; Lohse 1995:274-282). Die ontdekking van die evangeliese aard van God se geregtigheid het van Luther 'n vry mens gemaak. Vryheid is vir Luther vryheid van die dwang om jou menswees deur voortreflike werke te regverdig. Dít wat jy gedoen kry, bepaal nie jou aanvaarbaarheid by God nie. Wie dít snap, sê Luther, is vry om sy naaste in liefde te dien. Geloofsvryheid stel jou in staat om jou naaste langdurig in liefde te dien (vgl. Ebeling [1964] 2017:178-197; Schwarz [2015] 2016:91-94, 391-442).

'n Ander belangrike bydrae wat Luther tot die kerklike lewe en teologiese nadenke gemaak het, is dat daar reg onderskei moet word. Hy het ' $n$ paar keer gesê dat wie reg kan onderskei, is ' $n$ ware teoloog. Daar moet onderskei word tussen wet en evangelie, geloof en politiek, en kerk en wêreld. Wie werke met geloof verwar, is nie op die regte manier besig met die Bybel nie. Wie dink dat politiek godsdiens is, verstaan nie die Nuwe Testament nie, en wie sosiale ontwikkeling met die essensie van kerkwees verwar, lei die kerk op 'n pad van selfvernietiging. ' $n$ Kerk wat daarop aanspraak maak dat hy 'n Reformatoriese kerk is, maar nie kan insien dat geloof iets méér is as doenigheid en bedrywigheid nie, het nog nie met Luther, en Paulus, kennis gemaak nie (vgl. Ebeling [1995] 2015).

Volgens die Lutherse tradisie is geloof denkende geloof, maar nie blote denke nie. Luther se teologie word dikwels beskryf as 'konflikwetenskap', aangesien teologie en filosofie met mekaar in konflik staan. Luther en sy bondgenote (veral Philipp Melanchthon) het groot agting vir filosofie (wat 'n versamelnaam vir al die wetenskappe is) gehad. Danksy hierdie twee manne is wetenskaplike kennis en redelike nadenke binne die hoofstroom van die Protestantisme nog nooit as vyande van die kerk gesien nie. Wat Luther wel geleer het, is dat geloofsake nie filosofiese opinies is nie. Hy het die uniekheid en uitsonderlikheid van die geloofsartikels beklemtoon. Só het hy byvoorbeeld geargumenteer dat die 'maagdelike geboorte' filosofies onsin is, en slegs vanuit die geloof verstaan en beredeneer kan word. By Luther leer ons dat geloof en teologie méér is as 'n stuk werklikheidsverstaan. Luther leer dat geloof ook dink, maar dat denke as sodanig nie geloof is nie (vgl. Barth 2009:105-136; Ebeling [1964] 2017:79-99; Lohse 1995:214-222).

'n Belangrike vraag waarmee Luther geworstel het, is: Wat glo die gelowige? Die gelowige glo volgens Luther die evangelie - die evangelie wat te vind is in die Bybel. Geloof is aktiewe vertroue, maar het ook inhoud. Hierdie inhoud word in die Bybelse boodskap, wat verkondig word, gevind. Geloof glo nie die Bybel nie, maar die evangelie wat in die Bybel te vind is. Wie Luther navolg, is bevry van al die gekibbel oor die gesag en die inspirasie van die Bybel. Niemand het nog méér vir die Bybel gedoen as Luther nie (danksy hom het ons 'n Afrikaanse vertaling), maar met biblisisme en die getwis oor die vraag of die Bybel 'n handboek vir die wetenskappe is, het hy niks te make nie (vgl. Ebeling [1964] 2017:100-119; Lohse 1995:204-213; Schwarz [2015] 2016:27-74).

Een van Luther se goeie insigte is dat die evangelie nie met wêreldvertroue verwar moet word nie. Die vertroue dat die wêreldgeskiedenis, en dat elke afsonderlike volksgeskiedenis, breukloos in die koninkryk sal uitmond, is bygeloof en dwaling. Die sosiale orde en die stryd om sosiale geregtigheid, 
ten einde ' $n$ beter orde daar te stel, het weinig met geloof en die koninkryk te make. Die wisselgange en onvolmaaktheid van die wêreld is nie 'n openbaringsbron vir God en sy ryk nie. God word geken deur die kruis van Jesus Christus, terwyl die voetspore van die drie-enige God verborge bly in ons wêreld. Om hierdie rede het Luther onderskeid gemaak tussen die ryk van die wêreld en die ryk van God. Die 'tweerykeleer' het ten diepste te make met die twee gestaltes van geregtigheid - die geregtigheid van God in Christus, en die geregtigheid van die wêreld. Vertroue in wêreldse geregtigheid loop uit op teleurstelling, terwyl die geregtigheid waarvan Paulus praat, te make het met blywende hoop en vreugde. Luther moet nou ook nie doelbewus verkeerd verstaan word nie as sou hy gesê het dat die Christen geen morele verpligting het nie. Luther se argument is: Omdat ons nie die koninkryk kan laat aanbreek nie, kan ons, in gelatenheid, konsentreer op die relatiewe verbetering van sosiale omstandighede. Omstandighede verander wanneer elke gelowige, met konsentrasie op die liefdesgebod, volgens die eise van die tien gebooie lewe en werk. Wanneer elke Christen eerlik, hardwerkend en barmhartig is, sal die wêreld 'n draagliker plek gemaak word. Vir die groot strukturele veranderinge in die sosiale orde en die ekonomie is die politici verantwoordelik. Hierdie lot moet egter gereeld in gebed voor die Here gestel word - vir leiding, maar ook vir bestraffing - want inderdaad is hulle 'n korrupte spul (vgl. Ebeling [1964] 2017:198-218, 259-310; Lohse 1996:333-344; Schwarz [2015] 2016:443-478).

Ten spyte daarvan dat Luther sy hele lewe lank by politieke konflikte (soos die boereopstande) betrek was, was hy ten diepste 'n pastor wat hom besig gehou het met mense se pyn en lyding. Ná 500 jaar bly sy insigte oor die dood en die lewe ná die dood steeds bruikbaar. Sy mening dat die deelname aan Nagmaal goeie voorbereiding op die eie dood is, en die grootste troos bied vir diegene wat geliefdes aan die dood afgestaan het, bly vir my een van die belangrikste dinge wat ek by Luther geleer het. As 'n mens in één sin moet sê waar 'n samevatting van Luther se teologie te vind is, sal ek sê dat dit te vind is in die dankbare lofprysing van die klassieke Nagmaalformulier. Lof en dank aan die Here wat barmhartig en genadig is (Ps 103 en Rom 5), is die kern waaroor dit by Luther handel (vgl. Barth 2009:490-512; Bayer [2003] 2007:297303; Lohse 1995:345-355; Schwarz [2015] 2016:187-262).

\section{Erkenning Mededingende belange}

Die outeur verklaar dat hy geen finansiële of persoonlike verbintenis het met enige party wat hom nadelig kon beïnloed het in die skryf van hierdie artikel nie.

\section{Literatuurverwysings}

Barth, H.-M., 2009, Die Theologie Martin Luthers: Eine kritische Würdigung, Gütersloher Verlagshaus, Gütersloh.

Bayer, O., [2003] 2007, Martin Luthers Theologie: Eine Vergegenwärtigung, 3. Erneut durchgesehene Auflage, Mohr Siebeck, Tübingen.

Beutel, A. (Hg.), [2005] 2010, Luther Handbuch, 2. Auflage, Mohr Siebeck, Tübingen. (UTB 3416).
Deutsche Bibelgesellschaft, 2017, Die Bibel nach Martin Luthers Übersetzung. Lutherbibel. Revidiert 2017. Jubiläumsausgabe. 500 Jahre Reformation, mit Sonderseiten zu Martin Luthers Wirken als Reformator und Bibelübersetzer, DBG, Stuttgart.

Dietrich, V., [2008] 2013, Martin Luther: Sein Leben und seine Zeit, 3. Auflage, Deutscher Taschenbuch Verlag, München.

Dithmar, R. (hg.), 2010, Luthers Tischreden, Wartburg Verlag, Eisenach.

Ebeling, G., [1995] 2015, Theologie als Kunst des Unterscheidens, in C. Danz (Hrsg.), Martin Luther, pp. 84-128, Wissenschaftliche Buchgesellschaft, Darmstadt. (Neue Wege der Forschung: Theologie).

Ebeling, G., [1964] 2017, Luther: Einführung in sein Denken. Mit einem Nachwort von Albrecht Beutel, 6. Auflage, Mohr Siebeck, Tübingen.

Hamm, B., 2016, Ablass und reformation: Erstaunliche Kohärenzen, Mohr Siebeck, Tübingen

Jung, M., 2016, Luther lesen: Die zentralen Texte, bearbeitet und kommentiert von M.H. Jung, herausgegeben vom Amt der VELKD, Vandenhoeck \& Ruprecht, Göttingen.

Kaufmann, T., [2016] 2017, Erlöste und Verdammte: Eine Geschichte der Reformation, 2. Durchgesehene Auflage, C.H. Beck, München.

Kohnle, A, 2015, Martin Luther: Reformator, Ketzer, Ehemann, Evangelische Verlagsanstalt (SCM), Leipzig.

Kolb, R., Dingel, I. \& Batka, L. (ed), 2016, The Oxford handbook of Martin Luther's theology, Oxford University Press, Oxford.

Köpf, U., 2015, Martin Luther: Der reformator und sein Werk, Reclam Verlag, Stuttgart.

Kunter, K., 2016, 500 Jahre Protestantismus: Eine Reise von den Anfängen bis in die Gegenwart, Palm Verlag, Berlin.

Leppin, V., [2006] 2010a, Martin Luther, 2., durchgesehene, aktualisierte Auflage, Wissenschaftliche Buchgesellschaft, Darmstadt. (Gestalten des Mittelalters und der Rennaissance, Herausgegeben von Peter Herde).

Leppin, V., 2010b, 'Universitätswissenschaft', in A. Beutel (Hg.), Luther Handbuch, 2. Auflage, pp. 62-67, Mohr Siebeck, Tübingen. (UTB 3416).

Leppin, V., 2016, Die fremde reformation: Luthers mystische Wurzeln, Verlag CH Beck, München.

Leppin, V., 2017, Priestertum aller Gläubingen. Amt und Ehrenamt in der lutherischen Kirche, in U. Heckel, J. Kampmann, V. Leppin \& C. Schwöbel (Hrsg.), Luther heute: Ausstrahlungen der Wittenberger Reformation, pp. 149-169, Mohr Siebeck, Tübingen.

Lohse, B., 1995, Luthers Theologie in ihrer historischen Entwicklung und in ihrem systematischen Zusammenhang, Vandenhoeck, Göttingen.

Luther, M., 1883-1929, Weimarer Ausgabe (WA, WA DB en WA TR), D. Martin Luthers Werke: Kritische Gesamtausgabe, 65 Bände, H Böhlaus und Nachfolger, Weimar.

Luther, M., [1531-1546] 1912-1924, WA TR = Tischreden, Bände 1-6.

Luther, M., 1517 [2006], 'Disputatio pro declaratione virtutis indulgentiarum', WA 1233-1238, nuut opgeneem, in J. Schilling (Hrsg.), Martin Luther: LateinischDeutsche Studienausgabe. Band 2. Christusglaube und Rechtfertigung, pp. 1-15, Evangelischer Verlagsanstalt, Leipzig.

Luther, M., [1522] 2016, 'Vom ehelichen Leben' WA 10, II, 275-304, nuut opgeneem, in H. Zschoch (Hrsg.), Martin Luther: Deutsch-Deutsche Studienausgabe (DDStA 3). Band 3. Christ und Welt, pp. 165-215, Evangelische Verlagsanstalt, Leipzig.

Luther, M., [1524] 2016, 'An die Ratsherren aller Städte deutschen Landes, das sie christliche Schule aufrichten und halten sollen', WA 15, 27-53, nuut opgeneem, in H. Zschoch (Hrsg.), Martin Luther: Deutsch-Deutsche Studienausgabe (DDStA 3). H. Zschoch (Hrsg.), Martin Luther: Deutsch-Deutsche Studienausgabe (DDStA
Band 3. Christ und Welt, pp. 356-405, Evangelische Verlagsanstalt, Leipzig.

Luther, M., [1530] 2016, 'Predigt, dass man Kinder zur Schule schicken soll', WA 30, II, 517-588, nuut opgeneem, in H. Zschoch (Hrsg.), Martin Luther: Deutsch-Deutsche Studienausgabe (DDStA 3). Band 3. Christ und Welt, pp. 716-787, Evangelische Verlagsanstalt, Leipzig.

McKim, D., (ed.) 2003, The Cambridge Companion to Martin Luther, Cambridge University Press, Cambridge.

Melanchthon, P., [1546] 2011a, 'Oratio in funere reverendi viri D. Martini Lutheri', in M. van Beyer, S. Rhein \& G. Wartenberg (ed.), Melanchthon deutsch. Band 2. Theologie und Kirchenpolitik, 2., korrigierte Auflage, pp. 165-177, Evangelische Verlagsanstalt, Leipzig.

Melanchthon, P., [1546] 2011b, 'Historia Lutheri', in M. van Beyer, S. Rhein \& G. Wartenberg (ed.), Melanchthon deutsch. Band 2. Theologie und Kirchenpolitik, 2. korrigierte Auflage, pp. 178-197, Evangelische Verlagsanstalt, Leipzig.

Nürnberger, K., 2005, Martin Luther's message for us today: A perspective from the South, Cluster Publications, Pietermaritzburg.

Roper, L., 2016, Martin Luther: Renegade and prophet, Bodley Head, London.

Schilling, H., [2012] 2014, Martin Luther: Rebell in einer Zeit des Umbruchs, 3., durchgesehene Auflage, C.H. Beck, München.

Schilling, J., [2005] 2010, 'Aneignungen - Geschichtsbild und Selbstverständnis', in A. Beutel (Hg.), Luther Handbuch, 2. Auflage, pp. 97-106, Mohr Siebeck, Tübingen. (UTB 3416).

Schilling, J., 2017, 'Luther, die Musik und der Gottesdienst', in U. Heckel, J. Kampmann, V. Leppin \& C. Schwöbel (Hrsg.), Luther heute: Ausstrahlungen der Wittenberger Reformation, pp. 194-210, Mohr Siebeck, Tübingen.

Schwarz, R., 2010, 'Gattungen - Disputationen', in A. Beutel (Hg.), Luther Handbuch, 2. Auflage, pp. 328-340, Mohr Siebeck, Tübingen. (UTB 3416).

Schwarz, R., [2015] 2016, Martin Luther - Lehrer der christlichen Religion, 2. Auflage, Mohr Siebeck, Tübingen. 
Schweitzer, F., 2017, 'Die reformation als Bildungsbewegung - nicht nur im schulischen Bereich', in U. Heckel, J. Kampmann, V. Leppin \& C. Schwöbel (Hrsg.), Luther heute: Ausstrahlungen der Wittenberger Reformation, pp. 275-293, Mohr Siebeck, Tübingen.

Söding, T., 2017, 'Leuchtfeuer der reformation - Luthers Bibelübersetzung', in U. Di Fabio \& J. Schilling (Hg.), Die Weltwirkung der Reformation: Wie der Protestantismus unsere Welt verändert hat, pp. 73-80, C.H. Beck, München.

Strohm, C., 2017, 'Reformation und Recht', in U. Di Fabio \& J. Schilling (Hg.), Die Weltwirkung der Reformation: Wie der Protestantismus unsere Welt verändert hat, pp. 170-194, C.H. Beck, München.

Van Wyk, I.W.C., 2015a, 'Martin Luther oor oneerlikheid in die ekonomie', HTS Teologiese Studies/Theological Studies 71(3), Art. \# 2869, 1-7. https://doi. org/10.4102/hts.v71i3.2869
Van Wyk, I.W.C., 2015b, 'Martin Luther en teologiebeoefening in de toekoms', HTS Teologiese Studies 71(3), Art. \#3070, 1-8. https://doi.org/10.4102/hts. v71i3.3070

Van Wyk, N., 2016, 'Met dankbaarheid: 500 jaar Reformasie', in 2017 Gedenkalbum Nederduitsch Hervormde Kerk van Afrika, pp. 6-11, SENTIK, Pretoria.

Van Wyk, N., 2017a, 'Die 95 stellings oor die aflaat', Tydskrif vir Hervormde Teologie 5(1), 1-3.

Van Wyk, N., 2017b, 'Feit en fiksie oor die kerkdeur(e) van Wittenberg', Tydskrif vir Hervormde Teologie 5(1), 4-6.

Zschoch, H., [2005] 2010, Aneignungen - Lebenslauf, in A. Beutel (Hg.), Luther Handbuch, 2. Auflage, pp. 82-91, Mohr Siebeck, Tübingen. (UTB 3416). 